\title{
Management of the Da'wah of the Muhammadiyah Regional Leaders of Sinjai Regency during the Covid-19 Pandemic
}

\author{
Mursak $^{1}$, Kiki Rasmala Sani ${ }^{2}$ \\ 1,2 Universitas Muhammadiyah Sinjai \\ Email: uccamursak@gmail.com
}

\begin{abstract}
The impact Covid-19 pandemic is very big when we look at it from the quality and quantity side, where previously the community generally prayed in congregation in the mosque both in terms of quantity, but during the Covid-19 pandemic, we can see that in the field it has fallen greatly in terms of quantity. This study aims to determine the management carried out by the Muhammadiyah Regional Leaders (PDM) of the Sinjai Regency in conducting Da'wah during the Covid-19 Pandemic. The method used is qualitative research methods and data collection techniques through observation, interviews, and documentation. Data analysis techniques include data reduction, data verification, and concluding, the results of this study indicate that Da'wah Planning, Muhammadiyah Regional Leaders carry out Da'wah planning virtually by involving several Muhammadiyah Business Charities in Sinjai Regency. Also, during this pandemic in terms of quantity, there were more recitation participants than before the pandemic. Then in terms of controlling Da'wah, the PDM of the Sinjai Regency carried out control, namely evaluating in terms of the implementation of da'wah by always synergizing and coordinating with all Muhammadiyah charities in Sinjai Regency, starting from Ortom, Higher Education to Branch Leaders in each of the existing branches.
\end{abstract}

Keywords: Management, da'wah, Covid-19

\section{INTRODUCTION}

The Corona Virus Disease 2019 (Covid-19) pandemic that hit the unitary State of the Republic of Indonesia is something we cannot avoid without our efforts and strength (Arfan \& Sundari Nasution, 2021; Siste et al., 2020; Suprianto et al., 2020) Because of this, various researches have been carried out and even the efforts that have been made by the government to overcome this problem. Along with the development of the pandemic, we see from various media that the main impact of the pandemic is the economic sector (Association of Southeast Asian Nations (ASEAN), 2020; Nicola et al., 2020; Tisdell, 2020), on the one hand, the government with various policies issued such as limiting activities, limiting contact with other people or better known as social distancing, etc. Of course, this will have an impact on some of our daily activities as citizens, who have to make contact, either directly or indirectly, in fulfilling our basic needs in everyday life.

Apart from the impact of the Covid-19 pandemic on the economic sector, it also has an impact on other fields, such as the social, cultural, legal, religious, and so on (Friedler, 2021; Maboloc, 2020). Therefore, in general, this pandemic has an impact on all aspects of life. Both from the middle and upper classes such as those who have certain jobs in their daily life or from the middle to lower class groups such as those who do not have certain jobs in fulfilling their 
150 | Jurnal Administrare: Jurnal Pemikiran Ilmiah dan Pendidikan Administrasi Perkantoran

Volume 8, Issue 1, January-June 2021. Pages 149-156

basic needs for every day. For example, those in the middle and upper economic class who were going to their workplace smoothly suddenly with this pandemic they have to carry out their activities at home only / Work From Home (WFH) (Bhattacharjee, 2020; Chattopadhyay \& Pandit, 2020; P \& Shahid, 2020)as well as those in the middle to the lower class who previously they were fluent in carrying out their daily activities with people around him having to stay at home to prevent the spread of Covid-19.

Of course, these conditions will have an impact on the quality and quantity of our daily activities. Be it in the fields of economy, social, culture, religious law, and so on. Especially in the field of religion, of course, the impact is very big when we look at it from the quality and quantity side, where previously the community generally prayed in congregation in the mosque both in terms of quantity, but during the Covid-19 pandemic, we can see that in the field it has fallen greatly in terms of quantity. Likewise with the preachers. In fact, in preaching, we must pay attention to three elements, namely the conveyer of the message, the message conveyed, and the recipient of the message. Of these three elements, two things became a problem during this pandemic, namely the messenger and the recipient of the da'wah message, on the one hand, we are not recommended to gather people, then on the other hand, for the recipients of da'wah when viewed from a technology point of view (Fairozi \& Ayu, 2020; Hakim, 2021; Hamzah et al., 2019), only a small proportion have applications to communicate on the network (Online). Of course, this requires a strategy and/or management to deal with and go through it.

In the Sinjai Regency, especially the Muhammadiyah Organization, in this case, the Muhammadiyah Regional Leadership (PDM), of course, to always preach Amar Ma'ruf Nahi Munkar, it requires management or a strategy for all of that during the Covid-19 pandemic. Departing from this, as a prospective researcher would like to conduct research related to management carried out by the Muhammadiyah Regional Leaders in terms of preaching. By focusing on da'wah management, namely Takhthith (Da'wah Planning), Tanzhim (Organizing Da'wah), Tawjih (Movement of Da'wah), and Riqaabah (Control of Da'wah). By continuing to pay attention to and prioritizing Wasathiyah Islam (Islamic Teachings of Rahmatan Lilalamin) or as "middle" Islam to realize the best of the ummah.

\section{METHOD}

This research uses descriptive qualitative research. Bogdan and Taylor define qualitative research as a research procedure that produces descriptive data in the form of written or spoken words from people or observed behavior (Moleong, 2017). In this study, what will be described is how the management of Muhammadiyah Regional Leaders in conducting Da'wah during the Covid-19 pandemic. The informants in this study were: Chairman of the Muhammadiyah Regional Leadership Sinjai Regency; Deputy Chairmen of the Muhammadiyah Regional Leadership of Sinjai Regency; and the Secretary and Deputy Secretary of the Muhammadiyah Regional Leadership Sinjai Regency. Data collection techniques, namely observation, interviews, and documentation. The data analysis technique uses data reduction, data presentation, and conclusion drawing. 


\section{RESULT AND DISCUSSION}

Based on the results of data analysis conducted by researchers, it was found that the Muhammadiyah Regional Leadership of Sinjai Regency in conducting Da'wah during the Covid-19 pandemic about managerial elements, can be explained as follows:

\section{Planning}

Planning is the initial step of every activity that will be carried out, it is not uncommon for every activity that is carried out will be strongly influenced by the initial planning or in other words planning an activity. When the planning is good, it will be directly proportional to the output or outcome that we will get, but on the other hand, sometimes the planning is very good, but the results or outcomes that are not good are influenced by several things such as human resources and others inadequate, facilities and infrastructure to support the implementation of activities. these are inadequate and so on.

It is inseparable from the Regional Leadership of Muhammadiyah Sinjai Regency in terms of carrying out Da'wah planning during the Covid-19 Pandemic, of course, it must need a strategy or planning that is as effective as possible considering that during this Pandemic period, we can liken something that used to be all of us in a comfort zone suddenly we are faced with uncomfortable conditions with all restrictions in terms of carrying out activities or activities. Related to this, in the research it was found that the planning (Takhthith) carried out by the Muhammadiyah Regional Leaders of Sinjai Regency in terms of planning Da'wah during the Covid-19 pandemic, the Muhammadiyah Regional Leaders planned by holding virtual meetings using the Zoom Cloud Meeting application which involved several Muhammadiyah charities in Sinjai district. Apart from this, it also involved all Branch and Subdistrict Leaders in Sinjai Regency. The Da'wah plan that is carried out is the virtual recitation or in-network (online) by inviting, in turn, each branch leader and/or sub-branch leader to become a resource for the virtual recitation activity.

\section{Organizing}

Organizing in terms of wanting to carry out an activity is the second stage that must be carried out as, in the management concept, every activity that has been planned is, of course, to be carried out properly, of course, good organization is needed. Related to this, the findings in the study that the Muhammadiyah Regional Leaders of Sinjai Regency from several planned activities were organized by writing to the Branch leaders in terms of being used as a resource in the recitation to be carried out.

one of Muhammadiyah's (AUM) charities in this case the Muhammadiyah Sinjai University Campus through the AIK Research and Development Institute (LPP AIK) which conducts correspondence. This is because the Muhammadiyah Regional Leaders of the Sinjai Regency conducted a Memorandum of Understanding (MoU) with the Muhammadiyah Sinjai University in terms of conducting Da'wah during the Covid-19 pandemic. With this, every activity carried out by the Muhammadiyah Regional Leadership (PDM) of Sinjai Regency during the Covid-19 pandemic was made by LPP AIK Muhammadiyah University Sinjai as a partner of the Muhammadiyah Regional Leadership of Sinjai Regency. 
152 Jurnal Administrare: Jurnal Pemikiran Ilmiah dan Pendidikan Administrasi Perkantoran

Volume 8, Issue 1, January-June 2021. Pages 149-156

In general, the management of the Da'wah of the Muhammadiyah Regional Leaders (PDM) of Sinjai Regency in terms of organizing da'wah (Tanzhim) goes according to what is expected, namely the continued implementation of Da'wah during the Covid-19 pandemic.

\section{Movement}

Talking about the movement of da'wah, then this stage is the benchmark for what we have planned. Even though everything was well planned and then well organized but not carried out according to what was planned, the results will not be as expected.

During the Covid-19 pandemic, the Muhammadiyah Regional Leaders of Sinjai Regency conducted recitation twice a month involving branches and twigs in Sinjai Regency with the technical implementation carried out by the Institute for the Study and Development of Al Islam and KemuhammadiyahanMuhammadiyah Sinjai University as partners cooperation for the Muhammadiyah Regional Leaders of Sinjai Regency. During this activity, when we wanted to compare the recitation participants who were also present in the activity in terms of quantity, more recitation participants took part during the pandemic than before the Covid-19 pandemic, but in terms of quality or the output of this recitation was far from our expectations. general because most of the participants are more passive compared to actively paying attention to the recitation material witnessed online, this is in line with the results of interviews with several recitation participants who have been structured analysis research.

The above shows that sometimes what we have planned will not always reap the results according to our expectations in general, but there are several factors both internal and external that will influence these results, the researchers realize that the Regional Leaders of Muhammadiyah, Sinjai Regency has carried out the management or management of Da'wah during this Pandemic as well as possible, starting from the planning, organizing to carrying out the Da'wah. One thing we need to learn from this pandemic is that we are still thinking and thinking. It is proven that the Muhammadiyah Regional Leaders of Sinjai Regency continue to carry out Da'wah Amar Ma'ruf Nahi Mungkar even though the conditions are very difficult and not as comfortable as before.

\section{Control}

In the context of controlling Da'wah (Riqaabah), the researchers focused more on how the Muhammadiyah Regional Leaders of Sinjai Regency evaluated the implementation of Da'wah during the Covid-19 Pandemic.

From the results of the research conducted, it shows that the PDM of Sinjai Regency carries out control, in this case, the evaluation in terms of the implementation of da'wah by always synergizing and coordinating with all Muhammadiyah charities in Sinjai Regency, starting from Ortom, Higher Education to Branch Leaders in each of the existing branches. It is undeniable that during this online recitation, apart from the positive side or the advantages, many recitation participants (in this case who have an android cellphone) but on the other hand for those who do not have these facilities they cannot attend the recitation. Also, the signal or network factor that was not evenly distributed in each area resulted in the quality of the recitation being somewhat reduced.

But in general, from the implementation of Da'wah during this pandemic, in terms of quantity more participants participated than before the Covid-19 pandemic, but once again the researchers underline that in terms of quality it is very much different in other words decreasing 
the quality of the output of this Da'wah during and before the pandemic hit this country, including specifically in Sinjai District.

\section{Discussion}

\section{Planning}

Naturally, it is part of sunatullah, namely by seeing how Allah SWT created the universe with rights and careful planning and with the purpose of da'wah. In da'wah activities, da'wah planning is tasked with determining steps and programs in determining each target, determining preaching facilities or media, as well as preaching personnel to be deployed. Determine suitable material for perfect implementation, make assumptions about the various possibilities that can sometimes occur which can sometimes affect the way the program is implemented and how to deal with it, and determine alternatives, all of which are the main task of planning (Daraba et al., 2018; Sulanjari, 2020)

\section{Organizing}

Explain how the plan is managed, namely the implementation of the distribution of da'wah in more detail. achieve a predetermined goal. Meanwhile, Rosyid Saleh argued that the formulation of da'wah organizing was "a series of activities to compile a framework that becomes a forum for every da'wah business activity by dividing and grouping the work that must be carried out as well as establishing and arranging a working relationship between organizational units or their officers (Syamsiar et al., 2018).

\section{Movement}

It is the essence of da'wah itself, namely the entire process of providing work motivation to subordinates in such a way that they can work sincerely for the achievement of organizational goals efficiently and economically. Motivation is defined as the ability of a da'wah manager or leader to provide excitement, activity, and understanding so that members can support and work sincerely to achieve organizational goals according to the tasks assigned to them (Niswaty et al., 2019).

\section{Control}

Da'wah evaluation is designed to be given to the person being assessed and the person evaluating the information regarding the work. Da'wah management control can be said to a practical theoretical knowledge. Therefore, the preachers will be quicker to digest it if it is related to the behavior of the preachers themselves according to the organization. Thus, control of da'wah management can be categorized as part of applied behavior, which is oriented towards a demand for preachers about how to run and control a missionary organization that is considered good. But the most important thing is management commitment with one team in running a da'wah organization efficiently and effectively so that it can live up to the implementation of control (Khusrini \& Kurniawan, 2020).

The purpose of this evaluation is to achieve evaluative proselytizing conclusions and give consideration to the work and develop work in a program. While the evaluation of da'wah is considered important because it can guarantee the safety of the implementation and journey of 
154 | Jurnal Administrare: Jurnal Pemikiran Ilmiah dan Pendidikan Administrasi Perkantoran Volume 8, Issue 1, January-June 2021. Pages 149-156

the da'wah, know the various problems and problems faced as well as anticipatory and immediate solutions so that it will give birth to da'wah activists.

\section{CONCLUSION}

Based on the discussion of the research results, it can be concluded that the Regional Leadership of Muhammadiyah in Sinjai Regency in conducting Da'wah during the Covid-19 pandemic in managerial concepts was carried out through, namely 1) Planning; Muhammadiyah Regional Leaders carry out plans of Da'wah in a virtual way by involving several Muhammadiyah Business Charities (AUM) in Sinjai Regency; 2) Organizing; Da'wah is organized by writing to Branch leaders to become resource persons in the recitation and collaboration with LPP-AIK Muhammadiyah University Sinjai; 3) Movement; PDM Sinjai Regency is conducted twice a month by online or virtual; 4) Control of Da'wah (Riqaabah), PDM of Sinjai Regency carries out control in this case evaluation in terms of the implementation of da'wah by always synergizing and coordinating with all Muhammadiyah charities in Sinjai Regency, starting from Ortom, Higher Education to Subdistrict Leaders in each branch there is.

\section{REFERENCES}

Arfan, S., \& Sundari Nasution, M. (2021). Responsivity of Public Services in Indonesia during the Covid-19 Pandemic. Budapest International Research and Critics Institute (BIRCIJournal): Humanities and Social Sciences.

Association of Southeast Asian Nations (ASEAN). (2020). Economic Impact of Covid-19 Outbreak on ASEAN. Association of Southeast Asian Nations (ASEAN).

Bhattacharjee, S. (2020). 'Work from home' as an alternative to daily commuting for working women. Human Geographies. https://doi.org/10.5719/hgeo.2020.142.5

Chattopadhyay, S., \& Pandit, S. (2020). Freedom, distribution and work from home: Rereading engels in the time of the COVID-19-pandemic. TripleC. https://doi.org/10.31269/triplec.v19i1.1225

Daraba, D., Cahaya, A., Guntur, M., Aslinda, A., \& Akib, H. (2018). Strategy of governance in transportation policy implementation: Case study of bus rapid transit (BRT) program in Makassar City. Academy of Strategic Management Journal, 17(3).

Fairozi, A., \& Ayu, S. (2020). A Digitalisasi Dakwah. Jurnal Bimas Islam. https://doi.org/10.37302/jbi.v13i2.265

Friedler, A. (2021). Sociocultural, behavioural and political factors shaping the COVID-19 pandemic: the need for a biocultural approach to understanding pandemics and (re)emerging plobal Public Health. https://doi.org/10.1080/17441692.2020.1828982

Hakim, M. L. (2021). Manajemen Dakwah Pesantren Berbasis Daring: Studi pada Kanal Youtube AlamienTV. LENTERA. https://doi.org/10.21093/lentera.v4i2.2682 
Hamzah, N., Zainol, Z. N., \& Othman, H. (2019). A review on the needs analysis on online learning in islamic studies. In International Journal of Engineering and Advanced Technology. https://doi.org/10.35940/ijeat.E1124.0585C19

Khusrini, A., \& Kurniawan, T. (2020). Analysis of Implementation of E-Legislation Based on Public Participation at the National Law Development Agency. Jurnal Ilmiah Ilmu Administrasi Publik, 9(2), 125-136.

Maboloc, C. R. (2020). Globalization and consumer culture: social costs and political implications of the COVID-19 pandemic. Eubios Journal of Asian and International Bioethics.

Moleong, L. J. (2017). Metodologi Penelitian Kualitatif (Edisi Revisi). In PT. Remaja Rosda Karya.

Nicola, M., Alsafi, Z., Sohrabi, C., Kerwan, A., Al-Jabir, A., Iosifidis, C., Agha, M., \& Agha, R. (2020). The socio-economic implications of the coronavirus pandemic (COVID-19): A review. In International Journal of Surgery. https://doi.org/10.1016/j.ijsu.2020.04.018

Niswaty, R., Juniati, F., Darwis, M., Salam, R., \& Arhas, S. H. (2019). The Effectiveness of Leadership Functions Implementation in The Makassar Departement of Manpower. JPBM (Jurnal Pendidikan Bisnis Dan Manajemen), 5(1), 1-10.

P, S., \& Shahid, M. (2020). Work from home during COVID-19: Employees perception and experiences. Global Journal for Research Analysis.

Siste, K., Hanafi, E., Sen, L. T., Christian, H., Adrian, Siswidiani, L. P., Limawan, A. P., Murtani, B. J., \& Suwartono, C. (2020). The Impact of Physical Distancing and Associated Factors Towards Internet Addiction Among Adults in Indonesia During COVID-19 Pandemic: A Nationwide Web-Based Study. Frontiers in Psychiatry. https://doi.org/10.3389/fpsyt.2020.580977

Sulanjari, D. Y. (2020). E-Government Implementation in the Education Zone Service in Makassar City. Jurnal Ad'ministrare, 6(2), 153-158.

Suprianto, S., Arhas, S. H., \& Mahmuddin, M. (2020). The Effectiveness of Online Learning Amid the COVID-19 Pandemic. Jurnal Ad'ministrare, 7(2), 321-330.

Syamsiar, S., Saggaf, M. S., Salam, R., \& Ihsan, S. R. (2018). Implementation Of Supervision On Office Of Community Empowerment And Makassar City Village.

Tisdell, C. A. (2020). Economic, social and political issues raised by the COVID-19 pandemic. Economic Analysis and Policy. https://doi.org/10.1016/j.eap.2020.08.002 
156 | Jurnal Administrare: Jurnal Pemikiran Ilmiah dan Pendidikan Administrasi Perkantoran Volume 8, Issue 1, January-June 2021. Pages 149-156

This page is intentionally left blank 